\title{
Green Roof to Overcome Urban Heat Island Effects in the Center of Semarang
}

\author{
Dwi Nur Luthfiyyah ${ }^{1 *}$ and Retno Widjajanti ${ }^{2}$ \\ ${ }^{1}$ Student of Urban and Regional Planning Department, Faculty of Engineering, Diponegoro University, Semarang - \\ Indonesia \\ ${ }^{2}$ Lecturer of Urban and Regional Planning Department, Faculty of Engineering, Diponegoro University, Semarang - \\ Indonesia
}

\begin{abstract}
Climate change and urbanization are the main problems of the city that have caused the Urban Heat Island effect (UHI). A green roof that utilizes the building roof as a green space can overcome the UHI effects. Green roof is also an efficient solution in the procurement of green spaces in crowded cities. In 2019, Semarang City Mayor released regulation No. 24 of 2019 concerning Green Building that makes the focus of Semarang City development is to improve the urban environment. This research area is in two road corridors of Semarang City, Pandanaran and Pemuda roads. This study aims to examine the application of green roofs in these two corridors. Several identifications were carried out, first identifying building characteristics, second identifying opportunities for applying green roof, and third identifying building area capable of applying green roof. Primary data collection through field observations and satellite imagery as well as through questionnaires to the community who conduct activities in two roads corridors. The results of this study are the total roof area of $96,484 \mathrm{~m} 2$ from 30 buildings on Pandanaran road and 23 buildings on Pemuda road that can become new green spaces to overcome Urban Heat Island effects.
\end{abstract}

Keywords: Green Roof; Climate Change; Urban Heat Island (UHI); Buildings; City Center.

\section{Introduction}

Cities in the world are currently facing and trying to overcome the effects of climate change along with massive flows of urbanization. Urbanization causes $54 \%$ of the world's population currently living in cities and is expected to continue to increase by $70 \%$ in 2050 [1]. Climate change is the impact of building construction that does not pay attention to the availability of green space which triggers an increase in greenhouse gas emissions. Based on data from the [2], cities that continue to experience growth in the building construction sector directly increase the amount of greenhouse gas emissions by $3 \%$ every year between 2000 and 2010 and together with energy consumption from human activities significantly causes climate change. Therefore, cities need alternatives to provide green space to overcome the effects of climate change that are currently occurring.

Urban green infrastructure is an alternative in providing urban green space which is currently widely applied. Urban green infrastructure is defined as natural and semi-natural networks of urban green spaces such as forests, parks, green roofs, green walls that provide a natural environment within the city and as an effective solution to use costs for city development [6]. In fact, many cities are now working on building urban green infrastructure as an effort to overcome the effects of climate change. Therefore, climate change is a challenge for current spatial planners in the 21st century [5] that must be realized for the sake of the city's sustainability.

Green roof is one of the implementations of the city's green infrastructure, it turns out to have benefits as a natural filter for urban space with the provision of plants on the roofs of buildings. This makes green roof able to overcome the effects of climate change, such as the effect of Urban Heat Island (UHI) triggered by increased greenhouse gas emissions. The green roof concept was felt to be in accordance with the characteristics of a crowded city center and did not provide enough space for plants. This is also in line with the principle of city development according to [7] which states that currently, the city development principle has changed from the city beautiful to the city efficient.

UHI is a condition when the temperature in the city center is hotter than the temperature in the surrounding area, as experienced today in the city of Semarang. This is evidenced by reports from the Semarang City climatology station, the temperature in the city of Semarang tends to rise from $27.7^{\circ} \mathrm{C}$ in 2011 to $28.3^{\circ} \mathrm{C}$ in 2016. Semarang Mayor also planned the Semarang cooling plan program in response to the problem of increasing temperature due to UHI. The building

\footnotetext{
*Corresponding author: dwinluthfiyyah@gmail.com
} 
development sector becomes the face of the city, it should be able to hold a development that resolves problems rather than adding to problems. The Semarang City Government also responded to this problem with the Regulation of the Mayor of Semarang No. 24 of 2019 concerning green building which regulates the building construction sector. The two regulations prove that the focus of the development of Semarang City in the future is to improve the urban environment.

The increasing urbanization and land use in Semarang City should encourage new innovations in urban green infrastructure such as the procurement of green roofs. Green roof does not need additional space because it utilizes space on the roof of the building, this is an advantage compared to the application of other green infrastructure in its application in a crowded city center. This is also supported by the City of Semarang regulations which have implemented green building regulations. Therefore, this research is needed as a direction to overcome the effects of climate change in Semarang City Center through the application of green roofs.

\section{Methodology}

The method used in this study is descriptive quantitative obtained through field observations, satellite images, and questionnaires. Field observations were conducted to analyze the characteristics and opportunities of the 6 building functions in green building regulations including residential, office, retail, education, hospitals, and hotels. Observations through satellite imagery were carried out to obtain the existing building area through digitization, due to limited data and available data not up to date. Meanwhile, the questionnaire was conducted to get public perceptions regarding the condition of the air temperature and the application of green roof in the center of Semarang City. Several identifications were carried out, first identifying building characteristics, second identifying opportunities for applying green roof, and third identifying building area capable of applying green roof. This study uses 2 analyzes to explain 3 identification, first, analysis of the application of green roof in buildings and second, analysis of the benefits of green roof in buildings.

\section{Literature Review}

\subsection{Urban Heat Island Effect}

Climate change has an impact on Urban Heat Island (UHI) in cities with a dense level of urbanization such as Kuala Lumpur, Singapore, Hong Kong [8] and other South-East Asia Cities. Urban Heat Island is a hotter air condition in areas with high density compared to the surrounding area due to the absorption of buildings against solar radiation and lack of vegetation as air conditioning [10]. Based on the study of [9], it was found that air temperatures in dense areas that did not provide enough green open space were higher than those that provided enough green open space. This is because cities with a high level of urbanization cause maximum land use to be used as a built-up area.

\subsection{Green Roof}

The green roof is an area containing vegetation that is placed on the roof surface of a building that consists of layers of the substrate as a container of installation [3]. The modern green roof concept was implemented in Germany in the early 1960s when energy use continued to increase until an energy crisis occurred [4]. Germany applies a green roof to overcome the increase in energy use which has reached the stage of the energy crisis.

The green roof is still rarely applied especially in developing countries. There are still many buildings that are not in accordance with the needs of green roof installation, especially buildings that are already planned without considering the installation of a green roof. Existing buildings must be renovated in advance to be able to apply a green roof, this is also related to building load capacity. The first stage before implementing a green roof on existing buildings is to see the building's ability to receive loads from the green roof [12]. The ability to accept the load from the application of a green roof can be seen from the type of roof of the building.

\subsection{Opportunities for Green Roof Implementation}

\subsubsection{Semarang Mayor Regulation No. 24 of 2019 about Green Building}

The Semarang City Government issued green building regulations in order to support the implementation of sustainable buildings to improve environmental quality and encourage the saving of energy, water, and other resources. Semarang Mayor Regulation concerning Green Building No. 24 of 2019 regulates 6 building functions with 3 building area classifications. There are 6 functions that are regulated, including residential, office, retail, education, hospitals, and hotels. The classification of building area includes $<2,500 \mathrm{~m} 2,2,500$ $5,000 \mathrm{~m} 2$, and $>5,000 \mathrm{~m} 2$. This regulation is mandatory for new buildings and independently submitted by the building owner when submitting a Building Permit (IMB).

\subsubsection{Green City Policy by the Ministry of Public Works and Housing (PUPR)}

The Ministry of Public Works and Housing (PUPR) initiated the Green City Development Program (P2KH) in 2011. P2KH was initiated to create more qualified urban space through good planning and the realization of 8 green city attributes in accordance with the mandate of Law Number 26 of 2007 concerning Spatial Planning. There are 60 cities and regencies throughout Indonesia (including the City of Semarang) which carry out the 
green city action. These regions allocate regional development budgets for the Green City Action Plan. There are 2 out of 8 action items, namely Green Open Space and Green Building which are closely related and able to encourage the application of green roof.

\subsection{Benefits of Green Roof to Overcome Urban Heat Island Effects}

Vegetation is beneficial in reducing the amount of carbon in the air that causes climate change. Climate change that is currently happening is caused by development that is not followed by environmental preservation. One of the problems of climate change is the Urban Heat Island effects which are common in crowded city centers where land is built almost $100 \%$. Vegetation in urban areas through green roof is an effort to mitigate the problems of UHI [10]. Based on research by [13], that green roof can reflect solar radiation by $20-30 \%$ and absorb $>60 \%$ solar radiation for plant photosynthesis. The existence of green roof can be an alternative to vegetation planting in crowded urban centers to mitigate the impact of climate change in the form of UHI effects. Other benefits of green roof are listed in Table 1.

Table 1. The Benefits of Applying Green Roof

\begin{tabular}{|c|l|l|l|}
\hline No & $\begin{array}{l}\text { Green Roof } \\
\text { Benefits }\end{array}$ & \multicolumn{1}{c|}{ Multiplier } & \multicolumn{1}{c|}{ Source } \\
\hline 1 & $\begin{array}{l}\text { Reduce } \\
\text { energy } \\
\text { consumption }\end{array}$ & $\begin{array}{l}\text { 1 structure } \\
\text { (building) can save } \\
25 \% \text { energy }\end{array}$ & $\begin{array}{l}\text { Beckshire } \\
(2004)\end{array}$ \\
\hline 2 & $\begin{array}{l}\text { Reduce air } \\
\text { pollution }\end{array}$ & $\begin{array}{l}1 \mathrm{~m}^{2} \text { green roof } \\
\text { captures 0,2-2 kg } \\
\text { pollution material }\end{array}$ & $\begin{array}{l}\text { Minke (1982) } \\
\text { in Bass et al. } \\
(1999)\end{array}$ \\
\hline 3 & $\begin{array}{l}\text { Add space to } \\
\text { natural habitat }\end{array}$ & $\begin{array}{l}3.000 \mathrm{~m}^{2} \text { green roof } \\
\text { accommodates } \\
40.000 \text { plants }\end{array}$ & $\begin{array}{l}\text { www.science } \\
\text { links.jp } \\
(2011)\end{array}$ \\
\hline
\end{tabular}

\begin{tabular}{|c|l|l|l|}
\hline No & $\begin{array}{c}\text { Green Roof } \\
\text { Benefits }\end{array}$ & \multicolumn{1}{|c|}{ Multiplier } & \multicolumn{1}{c|}{ Source } \\
\hline 4 & $\begin{array}{l}\text { Water } \\
\text { management }\end{array}$ & $\begin{array}{l}\text { 144 liters } / \mathrm{m}^{2} \text { per } \\
\text { year }\end{array}$ & $\begin{array}{l}\text { Beckman } \\
(1997) \text { in } \\
\text { Peck \& Kuhn } \\
(2003)\end{array}$ \\
\hline
\end{tabular}

Source: Kinasih dan Mutaali, 2013

\section{Result}

\subsection{Analysis of the Application of Green Roof to Buildings in Semarang City Center}

The analysis of the application of green roof aims to identify buildings in Pandanaran and Pemuda roads, Semarang, which can apply green roofs. This analysis consists of 2 identifications, namely identification of building characteristics and identification of opportunities for applying green roof. Identification of building characteristics includes building coverage, private green open space, building type, roof type, and roof shape. Meanwhile, the identification of the opportunity to apply green roof is Semarang Mayor Regulation no. 24 which regulates 6 building functions.

Based on observations, there are 106 buildings on Pandanaran road and 116 buildings on Pemuda road which are included in the 6 building functions according to green building regulations. The results of this analysis identified 30 buildings on Pandanaran road (fig.1) and 23 buildings on Pemuda road (fig.2) that were able to apply green roofs. Buildings that can apply green roof are digitized via image maps to calculate the roof area of the building. The total roof area of the building is used as the basic data for calculating the benefits of green roof in the second analysis.



Fig. 1. Identification of Buildings in the Pandanaran Road Corridor that can Apply Green Roofs (Source: Author Survey, 2019) 


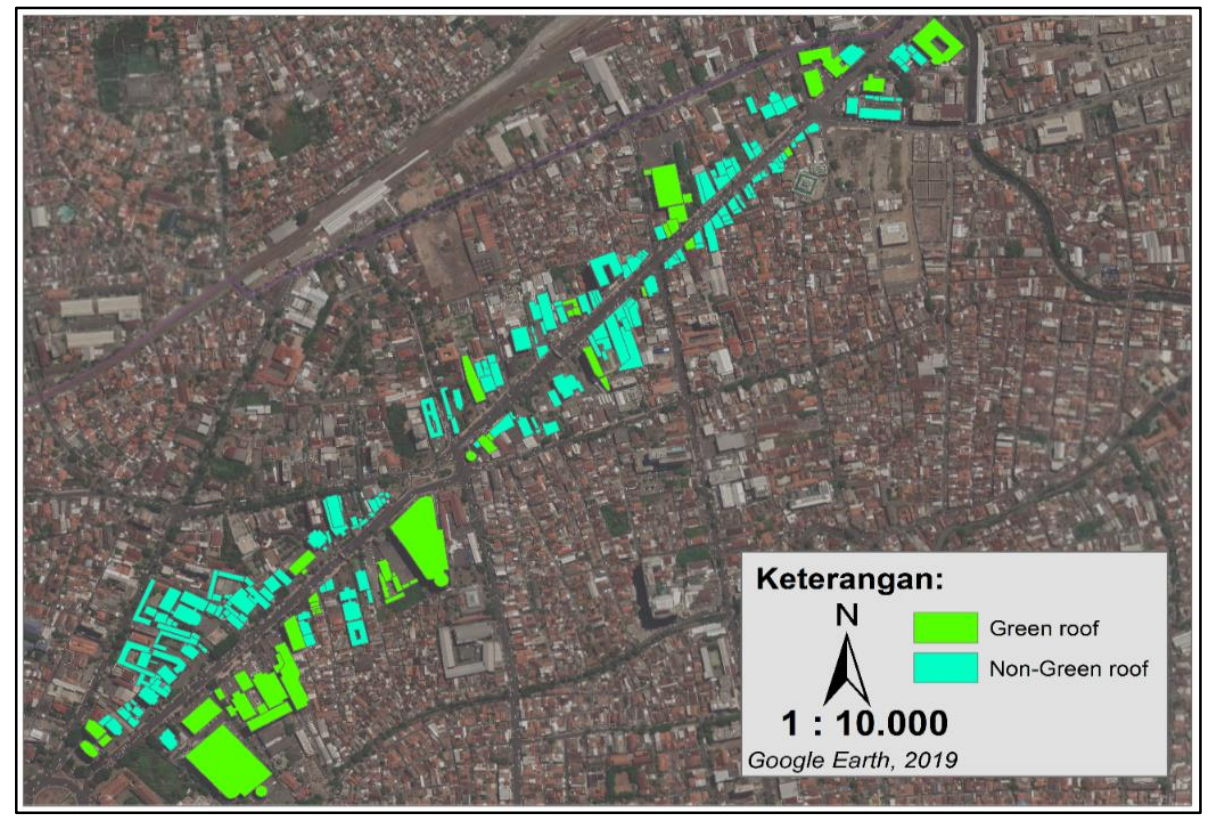

Fig. 2. Identification of Buildings in the Pemuda Road Corridor that can Apply Green Roofs (Source: Author Survey, 2019)

\subsection{Analysis of the Benefits of Implementing Green Roof on Pandanaran and Pemuda roads}

Analysis of the benefits of applying green roof using a total roof area resulting from the building that can apply green roof. The benefits of applying green roofs are calculated using the total roof area multiplied by multipliers obtained through previous theories (Table 2.). Based on the results of digitization, the total roof area of 30 buildings capable of applying a green roof on Pandanaran Road is $23,586 \mathrm{~m} 2$. Meanwhile, the total roof area of 23 buildings on Pemuda Road is $72,898 \mathrm{~m} 2$, so the two corridors have a total roof area of $96,484 \mathrm{~m} 2$ capable of applying green roofs. This number illustrates that there is $96,484 \mathrm{~m} 2$ of new green space in the city to overcome the urban heat island effects. Other benefits of a green roof are listed in Table 2.

Table 2. The Benefits of Applying Green Roof on Pandanaran and Pemuda Roads

\begin{tabular}{|c|c|c|c|}
\hline No & $\begin{array}{l}\text { Green Roof } \\
\text { Benefits }\end{array}$ & Multiplier & Result \\
\hline 1 & $\begin{array}{l}\text { Reduce } \\
\text { energy } \\
\text { consumption }\end{array}$ & $\begin{array}{l}1 \text { structure can } \\
\text { save } 25 \% \\
\text { energy }\end{array}$ & $\begin{array}{l}\text { Save } 25 \% \text { energy } \\
\text { for air conditioning }\end{array}$ \\
\hline 2 & $\begin{array}{l}\text { Reduce air } \\
\text { pollution }\end{array}$ & $\begin{array}{l}1 \mathrm{~m}^{2} \text { green roof } \\
\text { captures } 0,2-2 \\
\text { kg pollution } \\
\text { material }\end{array}$ & $\begin{array}{l}\text { - } 96.484 \times 0,2= \\
19.296,8 \mathrm{~kg} \\
\text { - } 96.484 \times 2= \\
192.968 \mathrm{~kg} \\
\text { Reduce } 19.968- \\
\mathbf{1 9 . 2 9 6 ~ k g ~ o f ~} \\
\text { pollution material on } \\
\text { both road corridors }\end{array}$ \\
\hline 3 & $\begin{array}{l}\text { Add space to } \\
\text { natural } \\
\text { habitat }\end{array}$ & $\begin{array}{l}3.000 \mathrm{~m}^{2} \\
\text { accommodates } \\
40.000 \text { plants }\end{array}$ & $\begin{array}{l}\text { - } \frac{96.484}{3.000} \times 40.000= \\
1.286 .453 \\
\text { plants }\end{array}$ \\
\hline
\end{tabular}

\begin{tabular}{|c|l|l|c|}
\hline No & $\begin{array}{c}\text { Green Roof } \\
\text { Benefits }\end{array}$ & \multicolumn{1}{|c|}{ Multiplier } & \multicolumn{1}{c|}{ Result } \\
\hline 4 & $\begin{array}{l}\text { Water } \\
\text { management }\end{array}$ & $\begin{array}{l}144 \text { liters } / \mathrm{m}^{2} \\
\text { per year }\end{array}$ & $\begin{array}{l}\text { - } 144 \times 96.484= \\
\mathbf{1 3 . 8 9 3 . 6 9 6} \\
\text { liter per year }\end{array}$ \\
\hline
\end{tabular}

Source: Author Analysis, 2019

\section{Conclusion and Recommendation}

\subsection{Conclusion}

Most of the buildings on the Pandanaran and Pemuda roads have not been able to apply the green roof without any physical changes. Only 30 of the 106 buildings on Pandanaran road and 23 of 116 buildings on Pemuda road that meet the physical criteria for applying green roof. In addition to building physical support, support from the local government in the form of special regulations related to the green roof is also needed, observing that most buildings on both roads do not have enough private green open space. Private Green space is important because optimization of vegetation can overcome the problem of climate change in the city center, namely Urban Heat Island Effects. The reason for applying the green roof is to overcome the problem because the green roof does not require additional land. This makes green roof suitable as the application of private green open space in the city center, especially in Semarang City.

\subsection{Recommendation}

The Semarang City Spatial Planning (RTRW) document has discussed green roof as a green space, but the green roof does not enter into the calculation of private Green Open Space (RTH). In fact, many buildings in the center of Semarang are unable to provide private RTH because the entire land is used optimally. Therefore, there is a 
need for special regulations related to the green roof, so that it is not only a compliment but also part of the provision of private green space, especially in buildings that have a maximum KDB. The application of green roof to buildings, especially in the center of Semarang, which has a high density is needed. Seeing the condition of the Semarang city center where most buildings have already been built without considering green spaces. The application of green roof to existing buildings cannot be applied to all buildings because not all buildings have a roof that can receive additional loads. The government as a policymaker can regulate the application of green roofs on existing buildings by following the stages carried out in this study.

\section{References}

1. United Nations, The 2014 Revision of the World Urbanization Prospects, Department of Economic and Social Affairs, Population Division (2014)

2. IPCC, Climate Change 2014: Synthesis Report. Contribution of Working Groups I, II and III to the Fifth Assessment Report of the Intergovernmental Panel on Climate Change, IPCC, Geneva, Switzerland (2014)

3. Growing Green Guide, Online.. Available: http://www.growinggreenguide.org. (2014)

4. M. Shafique, R. Kim M. Rafiq, Green roof benefits, oppurtunities and challenges - A review, Renewable and Sustainable Energy Review, 757773 (2018)

5. T. Measham, B. Preston, T. Smith, C. Brooke, R. Gorddard, G. Withycombe, Adapting to climate change through local municipal planning: Barriers and challenges, Mitigation and Adaptation Strategies for Global Change, 889-909 (2011)
6. S. Connop, P. Vandergert, B. Eisenberg, M. Collier, C. Nash, J. Clough, D. Newport, Renaturing cities using a regionally-focused biodiversity-led multifunctional benefits approach to urban green infrastructure, Environmental Science \& Policy, 99-111 (2016)

7. R. Adisasmita, Pembangunan Perdesaan dan Perkotaan, Yogyakarta: Graha Ilmu (2006)

8. A. Aflaki, M. Mirnezhad, A. Ghaffarianhoseini, A. Ghaffarianhoseini, H. Omrany, Z.-H. Wang, H. Akbari, Urban heat island mitigation strategies: A state-of-the-art review on Kuala Lumpur, Singapore, and Hong Kong, Cities, 131-145 (2017)

9. T. Susca, S.R. Gaffin, G.R. Dell'Osso, Positive effects of vegetation: Urban heat island and green roofs, Environmental Pollution, 2119-2126 (2011)

10. GSA, The Benefits and Challenges of Green Roofs on Public and Commercial Buildings, A Report of the United States General Services Administration, USA (2011)

11. Semarang Mayor Regulation No. 24 of 2019 concerning Green Building

12. S. Cascone, F. Catania, A. Gagliano, G. Sciuto, $A$ comprehensive study on green roof performance for retrofiting existing buildings, Building and Environment (2018)

13. U. Berardi, A. GhaffarianHoseini, State-of-the-art analysis of the environmental benefits of green roofs, Applied Energy, 411-428 (2014)

14. S. Kinasih, L. Mutaali, Potensi Pengembangan Teknologi Roof Garden di Kawasan Mampang Prapatan dan Sekitarnya, Jakarta Selatan, Jurnal Manusia dan Lingkungan, 252-261 (2013) 